\title{
OCCURRENCE AND POPULATION DENSITY OF APHIDS IN APPLE ORCHARDS OF SOUTH BULGARIA
}

\author{
Radoslav Andreev ${ }^{1 *}$, Donka Rasheva ${ }^{1}$, Hristina Kutinkova ${ }^{2}$ \\ ${ }^{1}$ Department of Entomology, Agricultural University, Mendeleev 12, 4000 Plovdiv, Bulgaria \\ ${ }^{2}$ Fruit Growing Institute, Ostromila 12, 4004 Plovdiv, Bulgaria
}

Received: March 28, 2013

Accepted: October 2, 2013

\begin{abstract}
In a 2006-2008 study, seven aphid species (Hemiptera: Aphididae) were detected on apple trees in South Bulgaria: Rhopalosiphum insertum Walk. (apple-grass aphid), Dysaphis plantaginea Pass (rosy apple aphid), Dysaphis devecta Walker (rosy leaf-curling aphid), Macrosiphum euphorbiae Thomas (potato aphid), Aphis pomi De Geer (green apple aphid), Aphis spiraecola Patch. (spiraea aphid/green citrus aphid) and Eriosoma lanigerum Nausm. (wooly apple aphid). The dominant species were D. plantaginea, found in $97.8 \%$ of the surveyed orchards. Two green aphid species from the genus Aphis were both found in $96.4 \%$ of the orchards. The rosy apple aphid was a more important pest of bearing orchards, where infestation in spring always exceeded the economic injury level (1-2\% of infested shoots). The green aphids were more important in young orchards and nurseries, where they developed during the entire vegetation period and infestation sometimes exceed $50-80 \%$ of shoots. A. pomi was still more widespread, but $A$. spiraecola was found throughout all of South Bulgaria. As pests of apple, the other species were less common, causing lower infestations and minor economic importance.
\end{abstract}

Key words: apple, aphids, infestation, Dyspahis plantaginea, Dysaphis devecta, Rhopalosiphum insertum, Macrosiphum euphorbiae, Aphis spiraecola, Aphis pomi, Eriosoma lanigerum

\section{INTRODUCTION}

Aphids are important pests that occur annually in apple orchards in Bulgaria. The economic injury level is infestation of $8-10 \%$ of shoots for the species that have less impact on the growth processes (such as green apple aphid). The economic injury level for species that cause stronger deformations (such as rosy apple aphid) is infestation of $1-2 \%$ of shoots (Stancheva et al. 2008). The last large-scale study on this group of pest insects in Bulgaria was conducted in the 1970's (Pelov 1977; Grigorov 1980). Since then, significant changes in the structure and size of apple orchards as well as in insecticides used and methods for control of this pests have taken place in Bulgaria. Hence, a new study on this group of pests was undertaken at the beginning of the $21^{\text {th }}$ century. The preliminary results of this survey were already reported by Andreev et al. (2007) and a new species for Bulgaria - Aphis spiraecola (spiraea aphid/green citrus aphid) was found.

The aim of the present study was to continue investigations aimed at a more precise assessment of species composition, distribution, and rate of infestation of apple trees by different species of aphids in South Bulgaria, where apple production is mainly located.

\section{MATERIALS AND METHODS}

The study was conducted in the 2006-2008 time period. In 2006, the data were collected only in the Plovdiv district. In the following two years, all (13) districts of South Bulgaria were surveyed - in 2007, the western part and in 2008, the eastern one. Within these districts, 137 apple growing micro-regions were separated (Fig. 1). In our study, each micro-region was represented by at least one representative apple orchard, but usually by $2-4$ neighbouring orchards. The studied orchards varied in age from 3 to 15 years old and older.

Records were taken of the incidence of aphids on at least 50 trees in each orchard, between the middle of May and the end of June. The observations in the Plovdiv district were carried out during the whole vegetation period. The percentage of trees infested with the wooly apple aphid ( $E r$ iosoma lanigerum) was determined. For the other aphid species, the percentage of infested shoots was estimated, based on an examination of 200-400 shoots, taken randomly in every orchard. The percentage of infested shoots for each location (micro-region) was then converted to the five-grade scale developed by Mikhailova et al. (1982), where grade 0 indicates no infested shoots; grade 1 - less than $5 \%$ infested shoots; grade 2 - between 5 and $15 \%$ of infested shoots; grade 3 - between 15 and $50 \%$ of infested shoots and grade 4 - more than $50 \%$ of infested shoots.

Additionally, the average percentage of infestation by Dyspahis plantaginea, D. devecta, E. lanigerum and for Aphis spp. (Aphis pomi and A. spiraecola together) was calculated for each district. These data were based on records from 4-5 micro-regions (locations) in small districts such as 


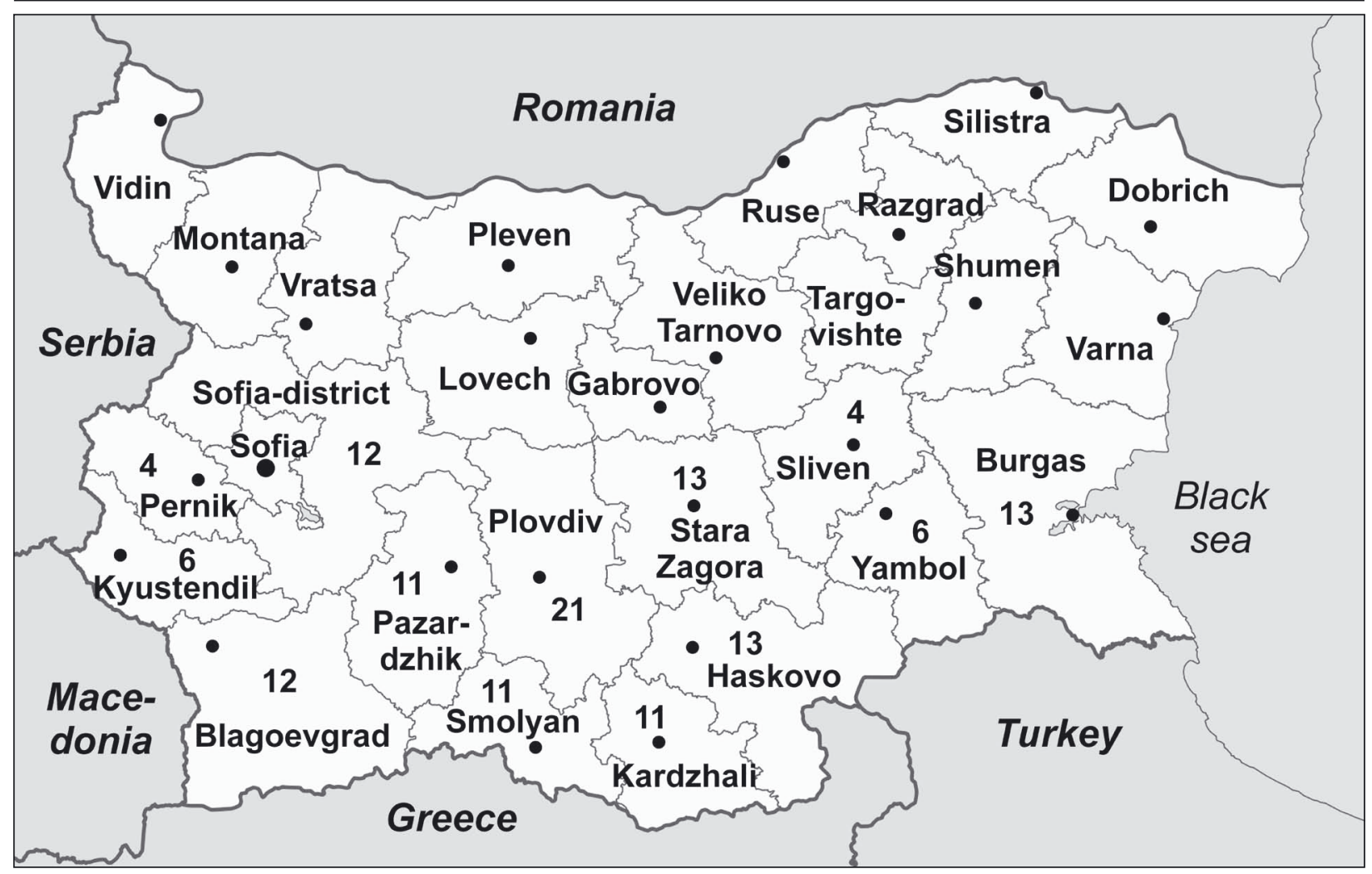

Fig. 1. Administrative map of Bulgaria with the number of the observed micro-regions in the districts of the southern part of the country

Kustendil, Pernik, Sliven and even up to 20 locations in large districts, like Plovdiv, Pazardzhik or Stara Zagora.

When the aphid species could not be visually identified by the colour of the individuals in a colony or by viewing the damage, microscope slides were prepared and the keys of Shaposhnikov (1964), Blackman and Eastop (1984), Leclant (2000) and Stekolshikov (2004) were used for identification.

\section{RESULTS AND DISCUSSION}

Seven aphid species (Hemiptera: Aphididae) were found feeding on apple trees in South Bulgaria: applegrass aphid (Rhopalosiphum insertum Walker.), rosy apple aphid (Dysaphis plantaginea Pass.), rosy leaf-curling aphid (Dysaphis devecta Walk.), potato aphid (Macrosiphum euphorbiae Thomas), green apple aphid (Aphis pomi De Geer.), spiraea aphid/green citrus aphid (Aphis spiraecola Patch./Aphis citricola van der Goot.), and woolly apple aphid (Eriosoma lanigerum Nausm.).

The survey of commercial orchards, carried out in May-June of 2007 and 2008, showed that infestation of apple trees by aphids in all areas of South Bulgaria was significant and exceeded the economic injury level (Fig. 2). The highest infestation was noted in the Plovdiv and Pazardzhik districts, which are the main fruit-growing regions in Bulgaria. An elevated infestation was also recorded in some other districts, such as Burgas, Sofia, Yambol, Sliven, Kurdzhali, Smolyan, and Blagoevgrad. The lowest infestation by aphids was noted in the districts of Pernik, Stara Zagora, Khaskovo, and Kyustendil.
The most common species was rosy apple aphid, $D$. plantaginea, which caused the highest infestation on apple shoots in May and June. Only in 3 out of 137 surveyed locations (micro-regions) was no pest found. The infestation exceeded $50 \%$ (grade 4 ) in ten locations, six of which were in the Plovdiv district. In the other micro-regions, infestation varied from $2-3 \%$ to $35-45 \%$.

Green aphids from the genus Aphis (green apple aphid, A. pomi and spiraea aphid, A. spiraecola) were also widespread in South Bulgaria. There were no species found in only five of the surveyed micro-regions. The infestations of apple shoots by these aphids, however, usually did not exceed 5\%. Infestation above the economic injury level was recorded in only 14 micro-regions.

The recently established aphid species $A$. spiraecola was found to be widespread throughout the whole southern part of the country. Colonies of it were detected in more than half of the investigated areas -72 locations, in all 13 districts (Fig. 3). The species showed a significantly higher density than green apple aphid $(A$. pomi) in the lowlands, whereas the density of its colonies was at a rather moderate level at altitudes lower than 500-600 meters. Already been found that A. spiraecola is displacing A. pomi from most of apple orchards in Plovdiv district (Rasheva and Andreev 2007). Colonies of A. pomi were detected in 90 locations; hence it may be concluded, that this species is still more widespread in South Bulgaria.

The green aphids are more important for young orchards and nurseries, where they find favourable conditions for feeding during the entire vegetative period. The infestation by these aphids in young orchards or nurseries sometimes exceeded $50-80 \%$ of shoots. 


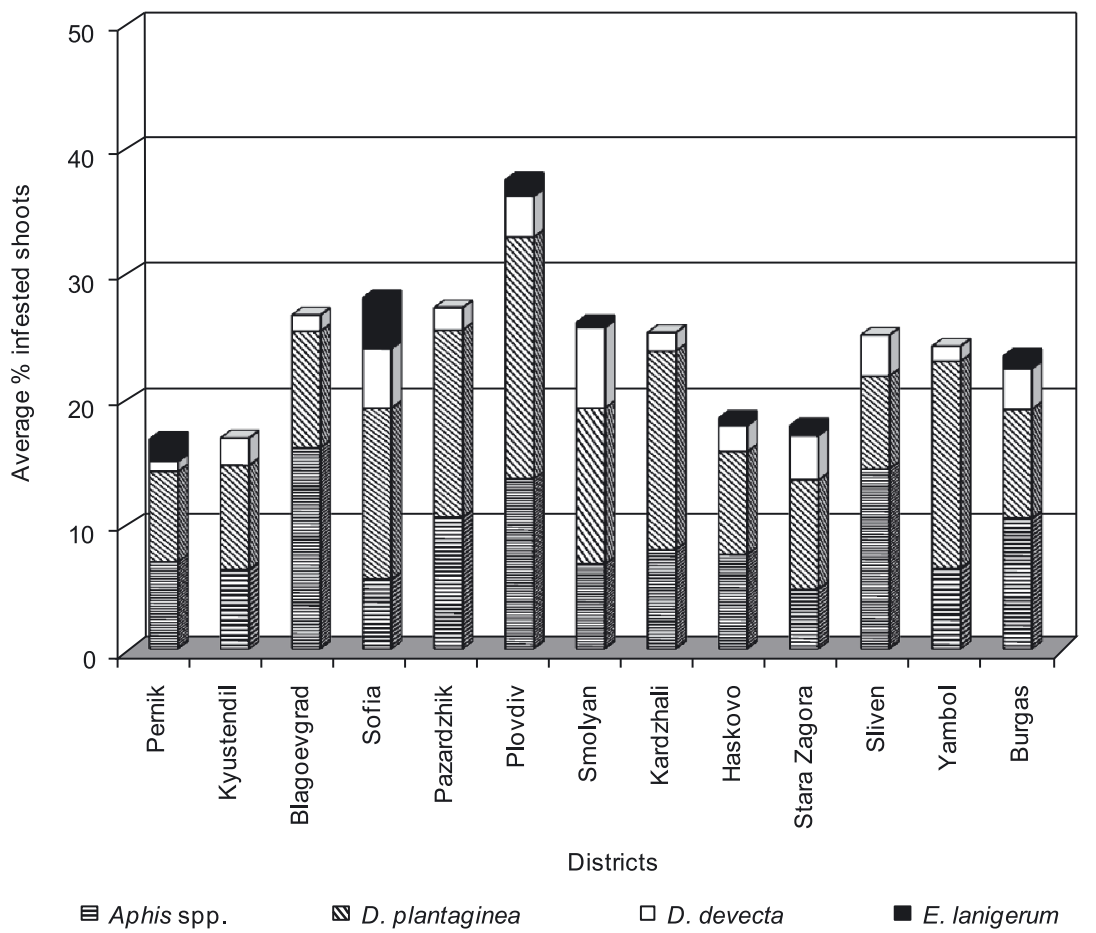

Fig. 2. Degree of infestation on apple trees by specific species of aphids in different districts of South Bulgaria (average values from all locations of each district)

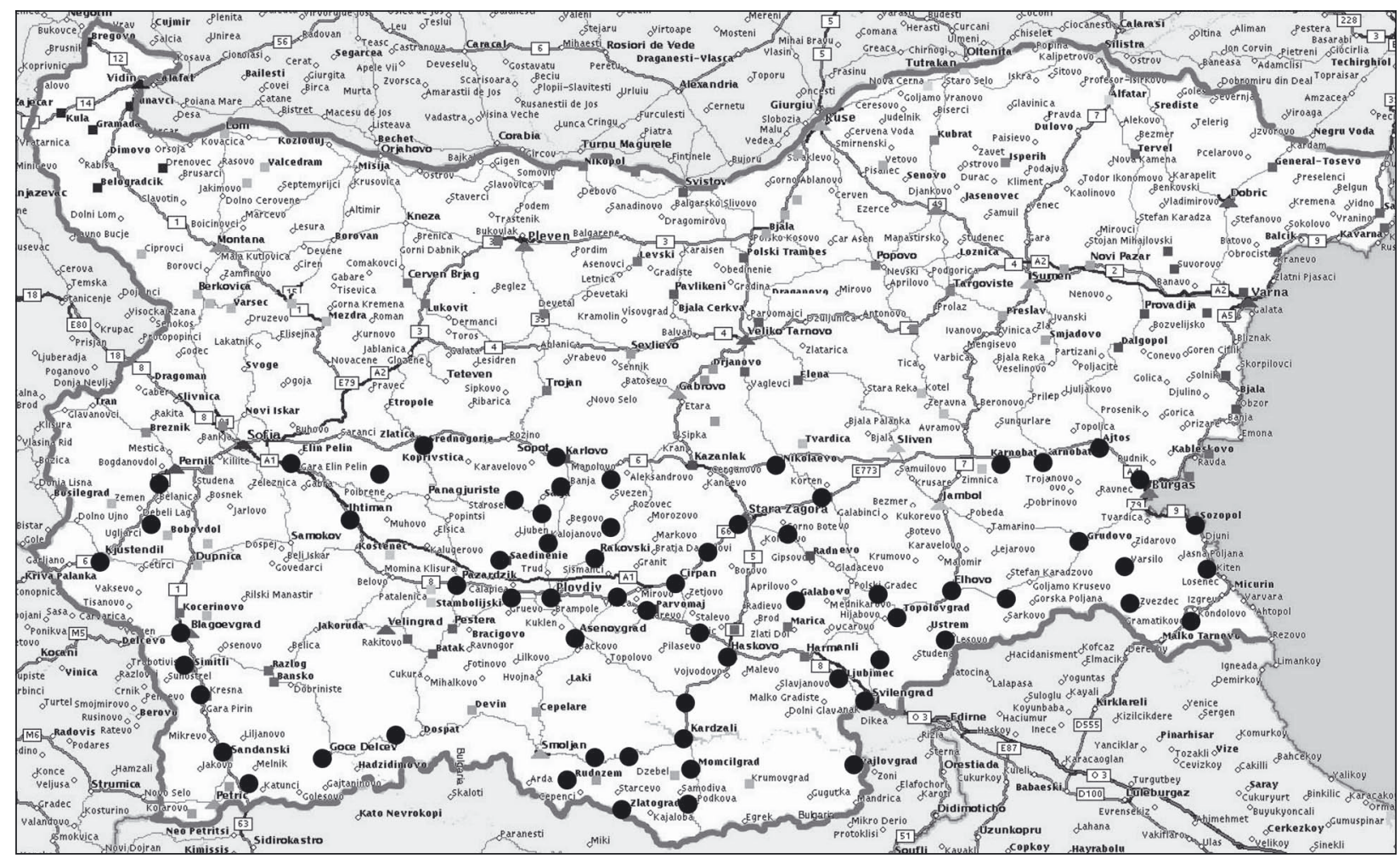

Fig. 3. Distribution of A. spiraecola in particular locations of South Bulgaria

The rosy leaf-curling aphid, $D$. devecta, was distributed in all districts, but was found in only 58 locations (from 137 surveyed) at a rather low population density.

The wooly apple aphid, E. lanigerum, was a less densely distributed aphid. Trees infested by this species were found in only 14 micro-regions, in 6 districts.
The apple-grass aphid (R. insertum) and potato aphid (M. euphorbiae) infest apple trees only during the early spring. After the bloom they migrated onto their summer hosts. Both species were found mainly at the sites of the Plovdiv district. 
Rhopalosiphum insertum was detected in all monitored (12) orchards near the city of Plovdiv, so apparently it was widespread in that area. However, damage caused by this species is not very important, because it develops only one fundatrix generation on apple.

Macrosiphum euphorbiae, which migrated somewhat later, was found in 11 micro-regions within 7 districts. This is the first report related to M. euphorbiae as a pest on apple in Bulgaria. The rate of shoots infested by this aphid never exceeded 1-2\% and this aphid has little importance as a pest.

Based on the results of our survey, it may be expected that the rosy apple aphid (D. plantaginea) presents the most important economic threat for commercial apple orchards of South Bulgaria. Green apple aphids from the genus Aphis may also cause some damage, in young orchards and nurseries in particular. Aphis spiraecola is already widespread throughout the whole South Bulgaria. The species apparently is displacing the common green aphid (A. pomi) from some areas, but $A$. pomi is still more common. The three mentioned species of aphids should be considered in control programmes in apple orchards. The other four species of aphids that were detected in South Bulgaria have little economic importance and only occasionally need to be controlled.

\section{REFERENCES}

Andreev R., Rasheva D., Kutinkova H. 2007. Aphids in apple orchards in Central-South Bulgaria. J. Plant Prot. Res. 47 (1): 109-112.

Blackman R.L., Eastop V.F. 1989. Aphids on the World's Crops. An Identification and Information Guide. Chichester, Wiley, UK, 470 pp.
Grigorov S. 1980. Listni Vashki i Borbata s Tyakh. [Leaf Aphids and their Control]. Zemizdat, Sofia, Bulgaria, $285 \mathrm{pp}$.

Leclant F. 2000. Les Pucerons des Plantes Cultivees Clefs D'identificatin. III - Cultures Fruitieres. [Aphids of Cultivated Plants. III - Fruit Crops]. INRA, Paris, France, 98 pp.

Mikhailova P., Straka F., Apostolov I. 1982. Rastitelno-Zashtitna Prognoza i Signalizatsiya. [Plant Protection Prognosis and Signalization]. Zemizdat, Sofia, Bulgaria, 344 pp.

Pelov V. 1977. Listni vashki po yabalkata i lyucernata i tekhnite estestveni vragove. [Aphids on apple and alfalfa and their natural enemies]. Spisanie Rastitel'na Zashtita 25 (2): 3-6.

Rasheva D., Andreev R. 2007. Aphis spiraecola Patch. (Hemiptera: Aphididae) nov nepriyatel po yabalkata v Balgariya. [Aphis spiraecola (Hemiptera: Aphididae) - a new pest on apple in Bulgaria]. Acta Entomologica Bulgarica $13(1,2)$ : 91-97.

Shaposhnikov G. 1964. Podotryad Aphidodea. [Subfamily Aphidodea - Aphids]. p. 489-616. In: “Opredelitel” Nasekomakh Evropeřskoŭ Chasti SSSR" [Identification Guide of Insects in the European Part of USSR] (G.Y. Beř-Bienko, ed.). Izdatel'stvo „Nauka”, Moskva-Leningrad, Russia, 1128 pp.

Stancheva Y., Borovinova M., Andreev R., Kalinova St., Balevski N., Simova S., Velcheva N., Staneva E., Draganova S., Arnaudov V., Kolev K., Stoev A., Rankova Z., Georgieva M. 2008. Guide for Integrated Pest Management in Fruit Crops. National Service of Plant Protection, Sofia, Bulgaria, $152 \mathrm{pp}$.

Stekolshikov A.V. 2004. The species complexes of aphids closely related to Dysaphis devecta (Walker) (Homoptera, Aphididae): Possible ways of its formation. p. 183-188. In: "Aphids in a new millennium" (J.-Ch. Simon, ed.). Proc. Sixth International Symposium on Aphids, INRA/ENSAR, Renne, France, September 2001, 549 pp. 